\title{
Blending Innovation Types in order to Achieve International Competitiveness. Multi-country Approach
}

\author{
MAŁGORZATA STEFANIA LEWANDOWSKA \\ Department of International Management \\ SGH Warsaw School of Economics \\ Al. Niepodległości 162; 02-554 Warsaw \\ POLAND
}

\begin{abstract}
The relationship between innovation and international competitiveness is the subject of many research studies. The aim of the paper is to examine the association between the introduction of product innovation individually and in pairs with process and marketing innovation and the exporting of enterprises from 13 European Union countries, mainly from Central and Eastern Europe. The study used anonymized micro data from the Community Innovation Survey (CIS) for 2012-2014. Based on the sample of 98809 enterprises, 14 models were built using path analysis with the Bonferroni correction, one for the whole sample and 13 for each of the country studied. The analysis indicates positive link between the introduction of product innovation on sales activity on foreign markets of the enterprises of the surveyed countries (measured by exporting), but only for Germany and Spain. Surprisingly, adding process or marketing innovation to product innovation in most of the cases has an adverse effect on exporting.
\end{abstract}

Key-Words: Product innovation, process innovation, marketing innovation, European Union, exporting, Community Innovation Survey.

Received: February 7, 2021. Revised: August 13, 2021. Accepted: August 24, 2021. Published: August $31,2021$.

\section{Introduction}

The purpose of the study is to examine the relationship between the introduction of technological (product, process) and nontechnological (marketing) innovation and sales orientation on foreign markets of enterprises (measured by exporting) from selected European Union countries.

In the literature, he relationship between innovation and international competitiveness has received a lot of attention, both at the macro- and microeconomic level [1;2]. Technological innovations are also a critical component in international competitiveness (at the branch level), which is indicated by technology gap theory [3].

The literature recognizes innovation and productivity as the main determinants of export performance of enterprises [4;5;6].

For example Filippetti, Frenz, \& Ietto-Gillies [7] in their study of a sample of companies from 32 European countries have found that companies that effect. Synergy is defined as mutual reinforcement, cooperation of factors, more effective than the sum spend more on innovation can compete on international markets and thus generate higher export sales.

The mainstream research focuses on the relationship of $R \& D$ and technological innovation (product and process) with the international competitiveness of enterprises, while research on non-technological innovation (marketing and organizational) and their impact on exports are less advanced [8].

Studies on the impact of complementarity of innovations (especially non-technological ones) on exports are relatively underdeveloped [9;10]. Moreover, although expanding, there is still less studies related to developing economies [11;12], than the developed ones. Complementarity is otherwise supermodularity - a concept introduced by Topkis [13] and developed by Milgrom and Roberts [14]. The aim of implementing complementary activities is to achieve the synergy

of their separate actions; is the maximization of the results obtained as a result of the implementation of 
mutually complementary activities. This principle also applies to innovation introduced in the enterprise [15].This text aims to reduce the research gap while investigating synergy effect of innovation among enterprises mostly coming from transition economies.

In the first part of the study, the literature review is presented. It is followed by the empirical part, where methodology is put forward. Results, discussion and conclusions make up the final parts of this manuscript.

\section{Literature Review}

The correlation between innovation and international competitiveness measured by exporting are the subject of research in many countries. Enterprises' worldwide competitiveness might be based on their product range (differentiation) or their cost advantage. Many studies undertaken at the macro- and micro levels show that in the long run, innovation resulting in a competitive advantage due to offer differentiation is more essential than innovation resulting in a cost advantage [16].

In this study, we assume that "innovation is the implementation of a new or significantly improved product (product / service) or process, a new marketing method or a new organizational method in business practice, workplace organization or relations with the environment" [17].

It is worth mention, that the latest edition of Oslo Manual introduced new definition as well as division of innovation (from four types: product, process, marketing and organisational) into product and business process innovation [18], but as CIS 2014 is based on the older division, similar definition and division is used in this paper.

Product innovation is one of the main factors building the international competitiveness of enterprises. In several industries, diversification of the offer (due, for example, to product innovation brought) has become a more significant component for exporter success than cost advantage, while in cost competition, maintaining a competitive level of quality is becoming increasingly vital (e.g. as an effect of innovation in products and processes introduced simultaneously) [19]. Furthermore, evaluations of the competition strategy of firms from Central and Eastern Europe on the worldwide market indicate that the role of elements connected to offer differentiation is growing [20].
Wagner [21] showed that investments in $R \& D$ resulting in product innovation have a positive impact on the company's decisions regarding sales involvement in foreign markets. Becker and Egger [22] in their study on German companies proved that product innovation is an important factor in strengthening the propensity to develop exports.

Tavassoli [23], based on two waves of Swedish CIS data from 2004 and 2006, as well as export-related data from 2008, it is discovered that enterprises' innovation output (measured as sales due to innovative products) has a positive and significant effect on their subsequent export behaviour, particularly on export intensity. The findings also reveal that there is no clear relationship between innovation input (innovative activities) and export behaviour. The author claims that the well-known strong relationship between productivity and export could be arriving through the innovation output channel, confirming the connection, but not in a direct fashion.

Investigating the relationship between the introduction of innovation of industrial enterprises of selected European Union countries and export is the content of the first research hypothesis:

\section{H1. The introduction of product innovation is positively related to enterprises' sales in foreign markets.}

In the case of process innovations, some researchers believe that its impact on export is unprovable [24]. Caldera's [25] findings, based on data from a representative panel of Spanish firms from 1991 to 2002, show that firm innovation has a general positive effect on the probability of participation in export markets, though product upgrading appears to have a stronger effect on exporting than the introduction of cost-saving innovation. A positive association between process innovation and export propensity was discovered among Colombian firms, but a negative and substantial relationship between process innovation and business age with the chance of exporting was also discovered [26].

Other authors, in turn, say that product innovations (enabling an advantage due to differentiation of the offer and adjustment to the conditions of the export market) are particularly important at the stage of entering the export market [4].

On the other hand, process innovation, often aimed at reducing costs and improving productivity-are conducive to obtaining a cost advantage, which is 
also important to the company's export commitment [27]. This is particularly evident in countries with a lower level of economic development [20;27;28].

The relation between product and process innovation dates back to works of Hayes and Wheelwright [29] and their Product Process Matrix, later developed by Abernathy and Townend [30], Abernathy and Utterback [31] and Hullova, Trott, Simms [32] and called Product-Process Complementarity Map.

The view on the complementarity of product and process innovations has been confirmed in many other empirical studies [15;33].

Di Maria and Ganau [34] found a positive impact of product innovation on decisions to undertake exports, and also showed that the intensity of exports is more strongly conditioned by process innovation than product innovation.

The need to differentiate the product or adapt it to the requirements of the export market may also require process innovation. In addition, process innovation focused on improving the cost competitiveness of the exporter can also stimulate product innovation, resulting in an increase in export intensity [35]. Lewandowska, Szymura-Tyc \& Golebiowski [10] showed a stronger positive impact on the export of new products in companies that introduced a combination of process and product innovation than in companies that only adopted product innovation.

Also Ballot et al. [36], based on the sample of CIS 2004 from Great Britain and France point out, that there is a complementarity between product and process innovation, although it is related to the country context, enterprise size and its resources.

Therefore, the following research hypothesis will be formulated:

H2. Blending the introduction of product with process innovation is positively related with enterprises' sales in foreign markets.

Literature indicates the positive impact of marketing competences, a distinct market strategy and marketing innovations on the results of enterprises [37]. Marketing communication increases market knowledge, stimulates bonds with the environment, which facilitates the development of new products. In turn, commercialization may require marketing innovation (like brand repositioning, changing distribution or promotion methods). Product and marketing innovations are considered complementary [38], which contributes to increasing the share of new products in total sales [39] and also increasing the intensity of exports [34].

Silva, Styles \& Lages [40] found that both technological and non-technological innovations have a positive impact on export performance. Also Boso, Adeola, Danso and Assadinia [41], proved that the ability to respond to market needs increases the intensity of export, in addition when it is implemented together with product innovation.

Slightly different results were obtained by Edeh, Obodoechi \& Ramos-Hidalgo [12]. They empirically explore the individual and joint impacts of technological and non-technological innovations on the export performance of SMEs from Nigeria. Based on data from two waves of the Nigerian version of the CIS between 2007 and 2010, they discovered that product innovation has a negative influence on export sales, whereas process innovation increases export performance. The combined effects of product, process, and marketing changes were significant, albeit with disparate consequences on export performance.

In the recently published article Gök and Peker [42] were looking at the relation between competences of work force from marketing department and marketing decisions on the development of innovation and firms innovation performance. The results confirm positive influence of marketing decisions on innovation performance as well as marketing competences on the development of product innovation.

Therefore, marketing competences and the resulting marketing innovation can be considered complementary to product innovation [43], although not all research results, especially of Polish enterprises, confirm this relationship [44]. Although the results are inconclusive, the above justifies the last hypothesis:

\section{H3. Blending the introduction of product with marketing innovation is positively related with enterprises' sales in foreign markets.}

\section{Methodology}

The analytical part of this study is based on the latest available anonymised microdata for European Union enterprises taking part in the Community Innovation Survey 2012-2014. The Community Innovation Survey (CIS) contains information on the innovative activity of enterprises from EU 
member countries, candidate countries, Iceland and Norway, collected using a uniform questionnaire and methodology based on the guidelines of the third edition of the Oslo 2005 Manual [17], which allows obtaining data comparable and harmonized. Target population are small, medium and large enterprises from NACE sections A to N.

Taking into account the adopted questionnaire layout, in which most of the questions refer to innovative enterprises, we accept, like other researchers [39], as a variable filtering information whether in the analysed period the enterprise introduced product and / or process innovation.

In the CIS questionnaire, it is possible to operationalize the company's innovative international activity by calculating export sales in 2014 as a percentage of sales in 2014. The details concerning the variables operationalisation are presented in Table 1.

Table 1. Variables Operationalisation

\begin{tabular}{|l|l|}
\hline Variable & Operationalization \\
\hline $\begin{array}{l}\text { Product innovation } \\
\text { Binary variable }\end{array}$ & $\begin{array}{l}\text { "1" "in case a new or significantly improved product is introduced to the market ahead of } \\
\text { competitors (it may already be available in other markets)", otherwise "0" or } \\
\text { "1" "when introducing a new or significantly improved product (which has already been } \\
\text { sold by competitors on the market)", "0" otherwise. }\end{array}$ \\
\hline $\begin{array}{l}\text { Process innovation. } \\
\text { Binary variable. }\end{array}$ & $\begin{array}{l}\text { "1" "for the introduction of new or significantly improved production methods for the } \\
\text { production of goods or services", otherwise "0" or } \\
\text { "1" "for the introduction of new or significantly improved methods of logistics, delivery } \\
\text { or distribution of goods or services", otherwise "0" or } \\
\text { "1" "when introducing new or significantly improved support activities for processes } \\
\text { such as maintenance systems or purchasing, accounting or calculation operations", "0" } \\
\text { otherwise. }\end{array}$ \\
\hline $\begin{array}{l}\text { Marketing } \\
\text { innovation. Binary } \\
\text { variable. }\end{array}$ & $\begin{array}{l}\text { a good or service (excluding changes that change the functional or utility features of the } \\
\text { product - these are product innovations)", otherwise "0" or } \\
\text { "1" "if the introduction of new media or product promotion techniques (i.e. first use of a } \\
\text { new advertising medium, new brand image, introduction of loyalty cards, etc.)", "0" } \\
\text { otherwise or } \\
\text { "1" "when new product placement methods or sales channels are introduced (i.e. first use } \\
\text { of franchise or distribution licenses, direct selling, exclusive retail, new product } \\
\text { presentation concepts, etc.)", "0" otherwise or } \\
\text { "1" "when introducing new methods of valuation of goods or services (i.e. application of } \\
\text { variable demand prices for the first time, rebate schemes, etc.)", "0" otherwise. }\end{array}$ \\
\hline $\begin{array}{l}\text { Exporting Binary } \\
\text { variable. "when indicated for exports as a percentage of total turnover from sales in 2014", "0" } \\
\text { otherwise. }\end{array}$ \\
\hline
\end{tabular}

Source: own elaboration based on CIS 2012-2014 questionnaire.

In our study we do not built constructs, and variables that enter further into the models are only binary. This allows for easy comparison between constructed models for 13 surveyed countries.

At this point, it is worth noting that indicator for export, although illustrating the importance of innovation in the company's product portfolio, have many weaknesses. Firstly, its size is strongly dependent on the rate of product renewal (product life cycle), and thus can take very different values in individual industries, and secondly, it reflects product innovation introduced in the enterprise to a greater extent, and the possible impact of process innovation can only be captured in indirect way [45].

The surveyed sample size, that initially covers 98 809 enterprises from 15 European Union countries (mainly from CEE region), include 26,168 from NACE section A, 25,408 from section B, 12,810 from section $C$ and 3,231 from section $D$. The rest of the sample $(31,192)$ comes from the rest of NACE sections, and cover also service enterprises. The split of the whole sample is shown in Table 2. 
Table 2. Sample Split

\begin{tabular}{|c|c|c|c|}
\hline ABR. & Country & Number & Percent \\
\hline BG & Bulgaria & 14255 & 14.4 \\
\hline CY & Cyprus & 1346 & 1.4 \\
\hline CZ & Czech Rep & 5198 & 5.3 \\
\hline DE & Germany & 6282 & 6.4 \\
\hline EE & Estonia & 1760 & 1.8 \\
\hline EL & Greece & 2507 & 2.5 \\
\hline ES & Spain & 30333 & 30.7 \\
\hline HR & Croatia & 3265 & 3.3 \\
\hline HU & Hungary & 6817 & 6.9 \\
\hline LT & Lithuania & 2421 & 2.5 \\
\hline LV & Latvia & 1501 & 1.5 \\
\hline NO & Norway & 5045 & 5.1 \\
\hline PT & Portugal & 7083 & 7.2 \\
\hline RO & Romania & 8206 & 8.3 \\
\hline SK & Slovakia & 2790 & 2.8 \\
\hline Total & & $\mathbf{9 8 ~ 8 0 9}$ & 100.0 \\
\hline
\end{tabular}

Source: own calculations in SPSS 21.

To verify research hypotheses, path analysis (a form of hierarchical multiple regression) developed by Sewall Wright $[46 ; 47 ; 48]$ was used.

Path Analysis examines strength of the linear direct and indirect relationship between a dependent variable and two or more independent variables. The strength of the overall influence of a given i-th variable (independent or intermediary) on the $j$-th variable is determined by the values of the correlation coefficients rij reproduced on the basis of the path coefficients.

The values of the path coefficients are estimated on the basis of the so-called fundamental equations of path analysis which has the following form:

$r_{i j}=\sum_{q} p_{i q} r_{i q}$

where:

$r_{i j}$ - correlation coefficient between the $i$-th and $j$-th variables,

p - path coefficient

q runs through all the variables, the paths of which lead directly or indirectly from the $j$-th to the $i$-th variable. It should be emphasized that the considered model creates a recursive system in which there are no feedback pressures, where individual variables could interact with themselves. Path Analysis is acknowledged as a statistical technique, but also as an approach towards building theory in social sciences. It guides exploratory and confirmatory research in a manner combining self- insight and modelling with theory. It often suggests novel hypotheses that were not previously considered. Later, bootstrap, the Bradley Efron method [49] was used to estimate the distribution of estimation errors, using multiple sample draws followed by a Bootstrap correction for goodnessof-fit measure [50]. For the needs of this study, 14 path models were built, one for the entire sample and 13 for each country surveyed (data from Bulgarian and Norwegian enterprises were incomplete, so these countries were not qualified for further study). The models examined the interaction between different types of innovation and exporting.

\section{Results}

In the examined path models, the Maximum Likelihood Estimation (MLE) method was used. Because the logic of maximum likelihood is both intuitive and versatile, it has become a dominating method of statistical inference.

After estimation of the tested theoretical model, a collection of information was obtained about the quality and fit of the model to empirical data, expressed in results of tests of goodness of matching the model to the empirical data matrix testing it.

Chi Fit Index Square $\chi 2$ verifies the hypothesis that the model matches the data. A value above 2 indicates its good fit.

The discrepancy between the theoretical and population variance-covariance matrix, corrected for the number of degrees of freedom, was examined by the RMSEA (Root Mean Square Error) factor. RMSEA is the average error of sample approximation to an ideal population. The model is fitted to the data when the value of this indicator is less than 0.05. A result of 0.08 is allowed [51].

For the tested model: Chi-square $=4.587, \mathrm{df}=1, \mathrm{p}$ $=0.032$ and RMSEA $=0.006$, which indicates a very good fit of the model to the data.

The analysis conducted for the whole sample showed that the introduction of product innovation is conducive to exporting, which provides the basis for maintaining hypothesis $\mathrm{H} 1$.

A significant relationship was found between the simultaneous introduction of product and process innovation and exporting, but in this case it was negative, similarly in the case of product and marketing innovation, so $\mathrm{H} 2$ and $\mathrm{H} 3$ were rejected. Details see Table 3. 
Table 3. Path model results for the entire sample and 13 European Union countries

\begin{tabular}{|c|c|c|c|c|c|c|c|}
\hline Variable & Dir. & Innovation type & $\mathrm{H}$ & Estimate & S.E. & C.R. & $\mathrm{P}$ \\
\hline \multicolumn{8}{|c|}{ Entire sample of enterprises, $\mathrm{N}=98809$} \\
\hline Exporting 14 & <--- & Product innovation & H1 & .037 & .002 & 16.358 & $* * *$ \\
\hline Exporting 14 & <--- & Product + process & $\mathrm{H} 2$ & -.009 & .003 & -3.074 & .002 \\
\hline Exporting 14 & $<--$ & Product + marketing & $\mathrm{H} 3$ & -.017 & .003 & -6.525 & $* * *$ \\
\hline \multicolumn{8}{|c|}{ Cyprus enterprises, $\mathrm{N}=1346$} \\
\hline Exporting 14 & <--- & Product innovation & H1 & -.039 & .029 & -1.350 & .177 \\
\hline Exporting 14 & <--- & Product + process & $\mathrm{H} 2$ & .028 & .031 & .898 & .369 \\
\hline Exporting 14 & $<--$ & Product + marketing & $\mathrm{H} 3$ & -.033 & .027 & -1.204 & .229 \\
\hline \multicolumn{8}{|c|}{ Czech Republic enterprises, $\mathrm{N}=5198$} \\
\hline Exporting 14 & <--- & Product innovation & H1 & .010 & .012 & .839 & .401 \\
\hline Exporting 14 & $<---$ & Product + process & $\mathrm{H} 2$ & .027 & .015 & 1.749 & .080 \\
\hline Exporting 14 & <--- & Product + marketing & $\mathrm{H} 3$ & -.049 & .012 & -4.195 & $* * *$ \\
\hline \multicolumn{8}{|c|}{ German enterprises, $\mathrm{N}=6282$} \\
\hline Exporting 14 & <--- & Product innovation & $\mathrm{H} 1$ & .132 & .011 & 12.403 & $* * *$ \\
\hline Exporting 14 & <--- & Product + process & $\mathrm{H} 2$ & .013 & .015 & .862 & .389 \\
\hline Exporting 14 & <--- & Product + marketing & $\mathrm{H} 3$ & -.018 & .013 & -1.387 & .165 \\
\hline \multicolumn{8}{|c|}{ Estonian enterprises, $\mathrm{N}=1760$} \\
\hline Exporting 14 & <--- & Product innovation & $\mathrm{H} 1$ & .002 & .021 & .077 & .939 \\
\hline Exporting 14 & <--- & Product + process & $\mathrm{H} 2$ & -.034 & .027 & -1.234 & .217 \\
\hline Exporting 14 & <--- & Product + marketing & $\mathrm{H} 3$ & .017 & .024 & .678 & .498 \\
\hline \multicolumn{8}{|c|}{ Greece enterprises, $\mathrm{N}=2507$} \\
\hline Exporting 14 & <--- & Product innovation & $\mathrm{H} 1$ & -.026 & .018 & -1.422 & .155 \\
\hline Exporting 14 & <--- & Product + process & $\mathrm{H} 2$ & .020 & .019 & 1.077 & .282 \\
\hline Exporting 14 & $<--$ & Product + marketing & $\mathrm{H} 3$ & -.027 & .015 & -1.790 & .073 \\
\hline \multicolumn{8}{|c|}{ Spanish enterprises, $\mathrm{N}=30333$} \\
\hline Exporting 14 & <--- & Product innovation & $\mathrm{H} 1$ & .020 & .003 & 5.723 & $* * *$ \\
\hline Exporting 14 & <--- & Product + process & $\mathrm{H} 2$ & -.002 & .005 & -.399 & .690 \\
\hline Exporting 14 & $<--$ & Product + marketing & $\mathrm{H} 3$ & -.009 & .004 & -2.279 & .023 \\
\hline \multicolumn{8}{|c|}{ Croatian enterprises, $\mathrm{N}=3265$} \\
\hline Exporting 14 & <--- & Product innovation & H1 & -.009 & .019 & -.468 & .640 \\
\hline Exporting 14 & <--- & Product + process & $\mathrm{H} 2$ & -.017 & .022 & -.758 & .449 \\
\hline Exporting 14 & <--- & Product + marketing & $\mathrm{H} 3$ & .020 & .017 & 1.152 & .249 \\
\hline \multicolumn{8}{|c|}{ Hungarian enterprises, $\mathrm{N}=6817$} \\
\hline Exporting 14 & $<--$ & Product innovation & H1 & -.008 & .008 & -.906 & .365 \\
\hline Exporting 14 & <--- & Product + process & $\mathrm{H} 2$ & .008 & .012 & .719 & .472 \\
\hline Exporting 14 & <--- & Product + marketing & $\mathrm{H} 3$ & -.004 & .011 & -.406 & .685 \\
\hline \multicolumn{8}{|c|}{ Lithuanian enterprises, $\mathrm{N}=2421$} \\
\hline Exporting 14 & <--- & Product innovation & H1 & -.010 & .017 & -.552 & .581 \\
\hline Exporting 14 & <--- & Product + process & $\mathrm{H} 2$ & .048 & .019 & 2.514 & .012 \\
\hline Exporting 14 & <--- & Product + marketing & $\mathrm{H} 3$ & -.031 & .015 & -2.104 & .035 \\
\hline \multicolumn{8}{|c|}{ Latvian enterprises, $\mathrm{N}=1501$} \\
\hline Exporting 14 & <--- & Product innovation & $\mathrm{H} 1$ & -.018 & .026 & -.682 & .495 \\
\hline Exporting 14 & <--- & Product + process & $\mathrm{H} 2$ & .026 & .031 & .856 & .392 \\
\hline Exporting 14 & <--- & Product + marketing & $\mathrm{H} 3$ & -.044 & .028 & -1.600 & .110 \\
\hline
\end{tabular}




\begin{tabular}{|c|c|c|c|c|c|c|c|}
\hline Variable & Dir. & Innovation type & $\mathrm{H}$ & Estimate & S.E. & C.R. & $\mathrm{P}$ \\
\hline Exporting 14 & <--- & Product innovation & $\mathrm{H} 1$ & -.003 & .006 & -.481 & .631 \\
\hline Exporting 14 & <--- & Product + process & $\mathrm{H} 2$ & .013 & .007 & 1.798 & .072 \\
\hline Exporting 14 & $<---$ & Product + marketing & H3 & -.013 & .005 & -2.401 & .016 \\
\hline \multicolumn{8}{|c|}{ Romanian enterprises, $\mathrm{N}=8206$} \\
\hline Exporting 14 & <--- & Product innovation & $\mathrm{H} 1$ & -.003 & .022 & -.130 & .896 \\
\hline Exporting 14 & <--- & Product + process & $\mathrm{H} 2$ & -.012 & .026 & -.458 & .647 \\
\hline Exporting 14 & <--- & Product + marketing & $\mathrm{H} 3$ & -.003 & .022 & -.130 & .896 \\
\hline \multicolumn{8}{|c|}{ Slovak enterprises, $\mathrm{N}=2790$} \\
\hline Exporting 14 & $<---$ & Product innovation & $\mathrm{H} 1$ & .098 & .050 & 1.952 & .051 \\
\hline Exporting 14 & <--- & Product + process & $\mathrm{H} 2$ & -.138 & .057 & -2.436 & .015 \\
\hline Exporting 14 & <--- & Product + marketing & $\mathrm{H} 3$ & .011 & .046 & .247 & .805 \\
\hline
\end{tabular}

Source: own calculations in SPSS 21.

$* * * \mathrm{p}<0,001, * * \mathrm{p}<0,01, * \mathrm{p}<0,05$

Analysing the results for individual countries, it should be pointed out, that the positive impact of introducing product innovation on exporting was demonstrated for enterprises from Germany and Spain, thus the $\mathrm{H} 1$ was confirmed for these countries only. Hypothesis $\mathrm{H} 2$ regarding the positive impact of product and process innovation introduced jointly has been confirmed only for companies from Lithuania.

$\mathrm{H} 3$ hypothesis confirming the positive impact of product and marketing innovations introduced jointly on exporting of the surveyed enterprises was not confirmed for any of the countries. On the contrary, in many cases (for enterprises from Czech Republic and Portugal) the negative impact of product and marketing innovation introduced together was detected. The summary of the results is presented in Tab. 4 .

Table 4. Summary of Obtained Results

\begin{tabular}{|c|c|c|c|}
\hline Country & H1 & H2 & H3 \\
\hline Cyprus & Rej. & Rej. & Rej. \\
\hline Czech Rep & Rej. & Rej. & Rej. \\
\hline Germany & Supp. & Rej. & Rej. \\
\hline Estonia & Rej. & Rej. & Rej. \\
\hline Greece & Rej. & Rej. & Rej. \\
\hline Spain & Supp. & Rej. & Rej. \\
\hline Croatia & Rej. & Rej. & Rej. \\
\hline Hungary & Rej. & Rej. & Rej. \\
\hline Lithuania & Rej. & Supp. & Rej. \\
\hline Latvia & Rej. & Rej. & Rej. \\
\hline Portugal & Rej. & Rej. & Rej. \\
\hline Romania & Rej. & Rej. & Rej. \\
\hline Slovakia & Rej. & Rej. & Rej. \\
\hline
\end{tabular}

Source: own elaboration based on the obtained results.
Rej. - Rejected hypothesis; Supp. - supported hypothesis.

\section{Discussion}

The purpose of this paper was to investigate the relationship between the introduction of innovation (product solely, pair of product with process and pair of product with marketing) on the export performance of enterprises from 13 European Union countries.

The obtained results, based on the CIS 2012-2014 data seem to confirm the conclusions of other researchers suggesting, that product innovation are more important in building companies' propensity to export than process innovation $[22 ; 28 ; 52 ; 53 ; 54]$. Literature suggest, that despite the fact that enterprises from emerging economies and in the transition period are still competing strongly based on the cost advantage (resulting from process innovation), their gradual orientation on the advantage resulting from differentiation (resulting from the introduction of product innovation) can be seen $[20 ; 27 ; 55 ; 56]$. Our study does not support these results, as the only positive and statistically significant link between product innovation and exporting has been revealed for Germany and Spain, which are advanced economies.

The adverse effect of innovation complementarity on export obtained in the case of product and process innovation (in the case of the whole sample, Lithuania, Slovakia) as well as for product and marketing innovation introduced simultaneously for the entire sample as well as for many single countries (Czech Republic, Spain, Portugal) may indicate the phenomenon of substitution, which in this case means the 
occurrence of negative interaction between different types of innovation.

To undertake process or marketing innovation means reducing the combined effect of introducing another innovation, e.g. product innovation. For example, marketing innovations accepted by customers can to some extent offset the relatively lower competitiveness of (new) solutions in the product; process innovations resulting in lower costs (and prices) can compensate for the lower innovative competitiveness of the product itself.

Research shows that this applies to a large extent to small and medium-sized enterprises, especially from low and medium technology industries [57;58].

To sum up, the presented study contributes to reducing the research gap on interaction between different types of innovation (technological and non-technological) and their impact on exporting.

\section{Conclusions}

The conclusions of the study indicate the legitimacy to analyse the substitutability of innovative activities in order to reduce unnecessary investments.

Future research could also focus on the reverse causality between exporting performance and innovation, which is a bases of many studies $[59 ; 60]$.

An interesting insight would potentially go from the research on the impact of one of external factors - that is consolidated VAT tax regime on the propensity of exporting of enterprises [61].

The authors are aware of the fact, that the study is not without limitations. First is the data set, that covers period 2012-2014. Whereas this period is not most up to date, it should be pointed out, that this is the latest available data set of CIS questionnaire on the micro level.

Analysis of dozen of works based in their empirical part on CIS data, shows, that the shortest period between the CIS wave and publication was 4 years, the longest was 12 years, while the average for all works was 8 years [62].

The limitations of the study also result from the standardization of the research tool itself. This is also reflected in simplified measure of international competitiveness as an exporting value, whereas the construct itself is much more multidimensional and can capture also not a pure export proportion but also take into account the price or differentiation advantage of exported product.
On the other hand, standardization means accepting similar definitions as well as allows for international comparisons, at least within the European Union countries, which is not possible due to numerous constraints, mainly financial, in the case of research conducted with the use of selfconstructed questionnaires.

Despite the above mentioned limitations, this study brings important contributions to the literature on innovation and international competitiveness and enrich still underdeveloped literature on developing economies. It also give some interesting insights for managers indicating, that pure export strategy based on product innovation brings better results than the one based on several of them.

Nowadays, the question stays, how Covid-19 pandemic will influence the behaviour of enterprises and customers. A survey carried by McKinsey [63] on more than 200 enterprises across industries shows, that almost $90 \%$ respondents say that they expect fundamental "change the way they do business over the next five years", and that the crisis „will have a lasting impact on their customers' needs". Many companies, "are deprioritizing innovation to concentrate on four things: shoring up their core business, pursuing known opportunity spaces, conserving cash and minimizing risk", and waiting until "there is more clarity".

In light of the research results we can suppose, that at least in the short perspective, the innovation activity of enterprises will diminish, as the day -today activities will dominate. On the other hand innovation is an important factor counteracting the negative effects of the economic crisis related to the COVID-19 pandemic. There is a clear need to develop innovative solutions, in particular in two areas: (1) communication and information technologies, which enable, inter alia, increasing the importance and improvement of tele-work, teleeducation and tele-medicine. This will increase health security and at least partially mitigate the effects of the difficulties caused by the pandemic, and (2) work on innovative drugs, in particular a vaccine against the COVID-19 virus [64]. New, reactive solutions concerning information flows are also needed to be developed [64].

\section{References:}

[1] Brusoni S., Cefis E. \& Orsenigo L, Innovate or die? A critical review of the literature on innovation and performance, Working Paper 
No. 179, 2006, Milan: CESPRI, Universita Commerciale Luigi Bocconi.

[2] Halpern, L, Literature survey on the links between innovation, competition, competitiveness, entry \& exit, firm survival and growth, MICRO-DYN, EU Sixth Framework Programme, Working Paper, 02/07, 2007.

[3] Soete L, A general test of technology gap trade theory, Weltwirtschaftliches Archiv, Vol. 117, 1981.

[4] Roper, S., Love, J. H, Innovation and export performance: evidence from the UK and German manufacturing plants, Research Policy, Vol. 31(7), 2002, 1087-1102.

[5] Leonidou, L. C., Katsikeas, C.,S., Palihavadana, D., \& Spyropoulou, S, An analytical review of the factors stimulating smaller firms to export. Implications for policy makers, International Marketing Review, Vol. 24(6), 2007, pp. 735770 .

[6] Wagner, J, Exports and productivity: A survey of the evidence from firm-level data, World Economy, Vol. 30(1), 2007, pp. 60-82.

[7] Filippetti, A., Frenz, M., \& Ietto-Gillies, G, Are innovation and internationalization related? An Analysis of European countries. Industry and Innovation, Vol. 18(5), 2011, pp. 437-459.

[8] Pino, C., Felzensztein, C., Zwerg-Villegas, A. M., \& Arias-Bolzmann, L, Non-technological innovations: Market performance of exporting firms in South America. Journal of Business Research, Vol.69(10), 2016, pp. 4385-4393.

[9] Carboni, O. A., Russu, P, Complementarity in product, process, and organizational innovation decisions: Evidence from European firms. $R \& D$ Management, Vol. 48(2), 2018, pp. 210-222.

[10] Lewandowska, M.S., Szymura-Tyc, M. \& Gołębiowski, T, Innovation complementarity, cooperation partners, and new product export: Evidence from Poland. Journal of Business Research, Vol. 69(9), 2016, pp. 3673-3681. DOI:10.1016/j.jbusres.2016.03.028.

[11] Bodlaj, M., Kadic-Maglajlic, S., \& Vida, I, Disentangling the Impact of Different Innovation Types, Financial Constraints and Geographic Diversification on SMEs' Export Growth. Journal of Business Research, Vol. 108, 2020, pp. 466-475. https://doi.org/10.1016/j.jbusres.2018.10.043.
[12] Edeh, J.N.; Obodoechi, D.N.; Ramos-Hidalgo, E. Effects of innovation strategies on export performance: New empirical evidence from developing market firms. Technological Forecasting and Social Change, vol. 158, 2020, DOI: 10.1016/j.techfore.2020.120167.

[13] Topkis, D.M, Minimizing a submodular function on a lattice. Operations Research, Vol. 26(2), 1978, pp. 305-321.

[14] Milgrom, P., Roberts, J., Complementarities and fit. Strategies, structure and organizational change in manufacturing. Journal of Accounting and Economics, Vol. 19(2-3), 1995, pp. 179208.

[15] Doran, J., Are differing forms of innovation complements or substitutes? European Journal of Innovation Management, Vol. 5(3), 2012, pp. 351-371.

[16] Montobbio F. Sectoral patterns of technological activity and export market share dynamics, Cambridge Journal of Economics, Vol. 27, 2003, pp. 523-545.

[17] Oslo Manual. Guidelines for Collecting and Interpreting Innovation Data. Joint publication by OECD and Eurostat, $3^{\text {rd }}$ ed., 2005, Paris: OECD Publishing.

[18] Oslo Manual. Guidelines for Collecting, Reporting and Using Data on Innovation. Joint publication by OECD and Eurostat, $4^{\text {th }}$ ed., 2018, Paris: OECD Publishing.

[19] Calantone R., Knight G. Role of Product Quality in International Performance of Industrial Firms, Industrial Marketing Management, Vol. 29(6), 2000, pp.493-506.

[20] Stojcic, N., Hashi, I., Telhaj, S., Innovation activities and competitiveness: empirical evidence on bahaviour of firms in new member states and candidate countries, CASE Network Studies and Analyses, 2011, 424.

[21] Wagner J., Export performance, human capital, and product innovation in Germany: A micro view, Jahrbuch für Wirtschaftswissenschaften. Vol. 47, 1996, pp. 40-45.

[22] Becker, S. \& Egger, P., Endogenous product versus process innovation and a firm's propensity to export. Empirical Economics, Vol. 44(1), 2013, pp. 329-354. 
[23] Tavassoli, S., The role of product innovation on export behavior of firms: Is it innovation input or innovation output that matters?, European Journal of Innovation Management, Vol. 21(2), 2018, pp. 294-314. https://doi.org/10.1108/EJIM-12-2016-0124.

[24] Dohse, D., Niebuhr, A. How different kinds of innovation affect exporting. Economics Letters, Vol. 163, 2018, pp. 182-185.

[25] Caldera, A., Innovation and exporting: evidence from Spanish manufacturing firms, Review of World Economy (Weltwirtschaftliches Archiv), Vol. 146 (4), 2010, pp. 657-689.

[26] Moreno-Gómez, J., Escandón-Charris, D., Moreno-Charris, A. Zapata-Upegui, L., Analysis of the role of process innovation on export propensity in KIBS and non-KIBS firms in Colombia", Competitiveness Review, 2020, (ahead pf print). https://doi.org/10.1108/CR-122019-0154.

[27] Lewandowska, M.S., Gołębiowski, T. Innovation and international competitiveness of manufacturing firms: Evidence from Bulgaria, Czech Republic, Hungary, Poland, and Romania, In: A. Zhuplev, K. Liuhto (ed.), GeoRegional Competitiveness in Central and Eastern Europe, the Baltic Countries, and Russia, IGI Global, Hershey PA, 2014, pp. 5782.

[28] Cieslik, A., Qu, Y., \& Qu, T. Innovations and export performance: Firm level evidence from China. Entrepreneurial Business and Economic Review, Vol. 6(4), 2018, pp. 27-47.

[29] Hayes, R. H., Wheelwright, S. C., Link manufacturing process and product life cycles. Harvard Business Review, 57(1), 1979, pp. 133-140.

[30] Abernathy, W. J., Townsend, P. L., Technology, productivity, and process change. Technological Forecasting and Social Change, Vol. 7, 1975, pp. 379-396.

[31] Abernathy, W.J., Utterback, J.M., Patterns of industrial innovation. Technological Review, (June-July), 1978, pp. 41-47.

[32] Hullova, D., Trott, P., \& Simms, C.D., Uncovering the reciprocal complementarity between product and process innovation. Research Policy, Vol. 45 (5), 2016, pp. 929940.
[33] Polder, M., van Leeuwen, G., Mohnen, P., \& Raymond, W., Product, process and organizational innovation: drivers, complementarity and productivity effects, $U N U$ MERIT Working Paper Series, 2010-035, 2010.

[34] Di Maria, E., Ganau, R., Driving firm's export propensity and export intensity: the role of experience, innovation and international marketing strategy. Paper presented on European International Business Academy (EIBA) 39 th Annual Conference, Bremen, 2013.

[35] Hervás-Oliver, J., Sempere-Ripoll, F. Disentangling the influence of technological process and product innovations, Journal of Business Research, Vol. 68 (1), 2015, pp. 109118.

[36] Ballot, G., Fakhfakh, F., Galia, F. \& Salter, A., The fateful triangle: complementarities in performance between product, process and organizational innovation in France and the UK. Research Policy, Vol. 44, 2015, pp. 217-232.

[37] Best, J. R., Market-based management. Strategies for growing customer value and profitability, $\left(5^{\text {th }}\right.$ ed.). Upper Saddle River, 2009, N.J: Pearson Education.

[38] Kotabe, M., Srinivasan, S.S., \& Aulakh, P.S., Multinationality and firm performance: The moderating role of $\mathrm{R} \& \mathrm{D}$ and marketing capabilities, Journal of International Business Studies, Vol. 33(1), 2002, pp. 79-97.

[39] Mothe, C., Nguyen T., \& Thuc U. The link between non-technological innovation and technological innovation, European Journal of Innovation Management, Vol.13(3), 2010, pp. 313-332.

[40] Silva, G. M., Styles, C., \& Lages, L. F., Breakthrough innovation in international business: The impact of tech-innovation and market-innovation on performance. International Business Review, Vol. 26(2), 2017, pp. 391-404.

[41] Boso, N., Adeola, O., Danso, A., \& Assadinia, S., The effect of export marketing capabilities on export performance: Moderating role of dysfunctional competition. Industrial Marketing Management, Vol. 78, 2019, pp. 137-145.

[42] Gök, O., Peker, S. The impact of marketing's innovation-related capabilities on firm's innovation performance, International Journal 
of Innovation Management, Vol. 24(6), 2020, pp. 687-717 https://doi.org/10.1142/S1363919620500541.

[43] Wang, K.-J., Lestari, Y.D., Firm competencies on market entry success: Evidence from a hightech industry in an emerging market. Journal of Business Research, Vol.(66), 2013, pp. 24442450.

[44] Szymura-Tyc, M., Rola i znaczenie marketingu we współczesnych procesach innowacyjnych. Zeszyty Naukowe. Uniwersytet Ekonomiczny w Poznaniu. Vol. 153, 2010, pp. 258-266.

[45] Mohnen, P., Mairesse, J., \& Dagenais, M., Innovativity: A comparison across seven European countries. UNU MERIT Working Paper Series, 2006-027. 1-57, 2006.

[46] Wright, S. Correlation and causation, Journal of Agricultural Research. Vol. 20, 1921, pp. 557-585.

[47] Wright, S., The method of path coefficients, Annals of Mathematical Statistics. Vol. 5(3), 1934, pp. 161-215.

Doi:10.1214/aoms/1177732676.

[48] Wright, S., Path Coefficients and Path Regressions: Alternative or Complementary Concepts?, Biometrics, Vol. 16(2), 1960, pp. 189-202. https://www.jstor.org/stable/2527551.

[49] Efron, B., Bootstrap methods: Another look at the Jackknife. The Annals of Statistics, Vol. 7(1), 1979, pp. 1-26.

[50] Bollen, K.A., Stine, R.A., Bootsrappingg goodness-of-fit measures in structural equation models. Sociological Methods Research, November, vol. 21(2), 1992, pp. 205-229.

[51] Konarski, R. (2010). Modele równań strukturalnych. Warszawa: PWN.

[52] Clausen, T.H., Pohjola, M., International competitiveness: internal capabilities and open innovation as sources of export performance. MICRO-DYN, EU Sixth Framework Programme. Working Paper, 05/09, 2009.

[53] Higón, D. A., Driffield, N., Exporting and innovation performance: Analysis of the Annual Small Business Survey in the UK. International Small Business Journal, Vol. 29(1), 2011, pp. 424.
[54] Saridakis, G., Bochra, I., Hansen, J. Dana, M., Leo, P., SMEs' internationalisation:When does innovation matter? Journal of Business Research, Vol. 96, 2019, pp. 250-263.

[55] Kirner, E., Kinkel, S., \& Jaeger, A., Innovation paths and the innovation performance of lowtechnology firms-An empirical analysis of German industry. Research Policy, Vol. 38(3), 2009, pp. 447-458.

[56] Wintjes, R., Douglas, D., Fairburn, J., Hollanders, H., \& Pugh, G., Beyond product innovation; improving innovation policy support for SMEs in traditional industries, UNU-MERIT Working Paper Series, 2014-03, 2014.

[57] Rammer, C., Czarnitzki, D., \& Spielkamp, A., Innovation success of non-R\&D performers: substituting technology by management in SMEs. Small Business Economics, Vol. 33(1), 2009, pp. 35-58.

[58] Kijek, T., An empirical analysis of the relationship between technological and marketing innovations: A case of Polish manufacturing firms, Acta Scientiarum Polonorum, Oeconomia, Vol. 12(2), 2013, pp. 15-25.

[59] Golovko, E., Valentini, G., Exploring the complementarity between innovation and export for SMEs' growth. Journal of International Business Studies, Vol. 42(3), 2011, pp. 362-380.

[60] Mińska-Struzik, E., Od eksportu do innowacji. Uczenie się przez eksport polskich przedsiębiorstw, 2014, Warszawa: Difin.

[61] Rudenko, V., Voloshchuk, R., Melnyk, V., Tsiupa, O., The Impact of Consolidated Value Added Taxation on Innovation and Investment Processes: European Experience and Prospects for Ukraine, WSEAS Transactions on Environment and Development, Vol. 17, 2021, Art. \#32, pp. 321-331.

[62] Lewandowska, M.S., Koncepcja otwartych innowacji. Perspektywa polskich przedsiębiorstw przemystowych, 2018, Warszawa: SGH Publishing House.

[63] McKinsey

https://www.mckinsey.com/businessfunctions/strategy-and-corporate-finance/ourinsights/innovation-in-a-crisis-why-it-is-morecritical-than-ever\#, 2020. 
[64] Kowalski, A.M; Lewandowska, M.S., Poznańska, K., Rószkiewicz, M., Godlewska, M., Mackiewicz, M., Poziom innowacyjności gospodarek krajów Europy Środkowej $i$ Wschodniej, Raport na Forum Ekonomistów, Krynica 2020, 2020, Oficyna Wydawnicza SGH, Warszawa.

[65] Chłodnicka, H, Threat to business activity in times of the pandemic, WSEAS Transactions on Business and Economics, Vol. 18, 2021, Art. \# 10. Pp. 88-94.

\section{Contribution of individual authors to the creation of a scientific article (ghostwriting policy)}

Małgorzata Stefania Lewandowska is responsible for theoretical part, hypotheses formulation, statistics.

\section{Sources of funding for research presented in a scientific article or scientific article itself}

The work has been supported by the funds from the Ministry of Education and Science in Poland granted for SGH Warsaw School of Economics, project number KGŚ / S20: 1.10

\section{Creative Commons Attribution \\ License $\quad 4.0 \quad$ (Attribution $\quad 4.0$ International, CC BY 4.0)}

This article is published under the terms of the Creative Commons Attribution License 4.0 https://creativecommons.org/licenses/by/4.0/deed.e n_US 